\title{
"State of Intoxication:" Governing Alcohol and Disease in the Forests of British North Borneo
}

\author{
David R. Saunders \\ https://orcid.org/0000-0003-2836-3906 \\ The University of Hong Kong, Hong Kong
}

\begin{abstract}
This article focuses on issues of alcohol consumption, disease and public health in British North Borneo in the 1920s and 1930s, a colonial territory along the periphery of empire. Drawing upon a range of sources - from reportage and memoranda, to local folk tales and oral tradition - it examines how the North Borneo Chartered Company administration responded to spiralling population decline and ill health amongst indigenous Murut communities. Amidst widespread economic stagnation, the company shunned vital public health infrastructure and medical aid, opting instead to govern behaviour and condemn alcohol consumption. This article shows how the company perpetuated racist assumptions concerning ostensible alcohol addiction amongst indigenous communities. It further suggests that the effects of Northern European and American temperance and prohibition movements impacted the Bornean tropics. While scholarly attention has been paid to issues of alcohol, disease and empire in the tropics, historiography has overlooked the role of lax colonial governance in semiautonomous, atypical colonial spaces such as British North Borneo. This article ultimately serves as a vital corrective by showing how the legacies of commercial-colonial governance remain perceptible in Sabah today, a region still facing major socio-economic and public health pressures amidst the ongoing COVID-19 pandemic.
\end{abstract}

Keywords: British North Borneo, alcohol addiction, Murut depopulation, public health, tropical disease, colonial governance, Sabah, Southeast Asia

eTropic: electronic journal of studies in the tropics publishes new research from arts, humanities, social sciences and allied fields on the variety and interrelatedness of nature, culture, and society in the tropics. Published by James Cook University, a leading research institution on critical issues facing the world's Tropics. Free open access, Scopus Listed, Scimago Q2. Indexed in: Google Scholar, DOAJ, Crossref, Ulrich's, SHERPA/RoMEO, Pandora. ISSN 1448-2940. Creative Commons CC BY 4.0 free to download, save and reproduce. To cite, include: Author(s), Title, eTropic, volume, issue, year, pages and DOI: http://dx.doi.org/10.25120/etropic.20.1.2021.3779 
eTropic 20.1 (2021) Special Issue: Pandemic, Plague, Pestilence and the Tropics

\section{A Drinking Colony? Colonial Imaginaries of Borneo}

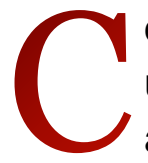

olonial imaginaries frequently cast the Southeast Asian tropics as inherently unhealthy and ungovernable. Nevertheless, imperial strategists and colonial agents also deemed the region as vital to colonise owing to its untapped strategic and economic value. Indeed, the emergence of an array of semi-autonomous colonial states across the island of Borneo in the late nineteenth century brought these issues to the fore.

As a simultaneously resource-rich and yet ostensibly disease-ridden island, desires to impose colonial authority, maintain social order and create a healthy built environment ranked high in colonial minds. While governing circles in British North Borneo (present day Sabah) addressed questions relating to sanitation, public behaviour and disease management, their policies primarily centred on maintaining healthy colonial lives, and on the preservation of colonial enterprise in its various forms (Copeland, 1935). Little serious concern was extended to "native" lives in the tropical hinterlands, where rural hospitals were little more than "dirt-floor sheds with stretchers or benches" (Manderson 1999, p. 103) and with so-called "jungle dispensaries" few and far between (Copeland 1935, p. 1235) (Figures 2 and 3). Inequalities in policy from afar bred even greater contrasts in public health on the ground, where indigenous ill health, mortality and depopulation were determined to derive from behavioural faults.

In the 1920s and 1930s, these issues played out in the pages of colonial memoranda and reportage, as well as in the burgeoning literature that engaged readers in the West. From the whisky and gin pahit-drinking bureaucrats of William Somerset Maugham's 'Before the Party' and other short stories (Maugham, [1922] 2000), to the colonial reports that poured scorn over alleged sightings of "native" babies being fed alcoholic tapai [rice beer or wine] (Cook, [1924] 2007, p. 23), the purported perils of alcohol garnered significant attention. Across the United States and North-western Europe, Protestant temperance and prohibition movements accelerated in the early twentieth century. The religious, moralistic and economic dimensions of such movements from the temperate north permeated even the remote tropics of Borneo, where advocates of temperance jostled for attention with anti-slavery and antigambling lobbies in colonial circles. Indeed, examining the contested status of alcohol in British North Borneo in the 1920s and 1930s offers historians an important window into how such issues affected indigenous lives and colonial administrative practices in the tropics.

The British North Borneo Company's anxieties over alcohol abuse, and at times its selective promotion of temperance, developed paradoxically amidst a widening colonial disregard for indigenous public health. Diseases and epidemics increasingly 
eTropic 20.1 (2021) Special Issue: Pandemic, Plague, Pestilence and the Tropics

ran rife amongst impoverished and marginalised communities in the 1920s. Routine outbreaks of hookworm, malaria, amoebic dysentery, influenza and measles, among other diseases, devastated indigenous Murut (and to a lesser extent Kadazandusun) communities (Copeland, 1935). The Murut, a minority ethnic group that constituted 9 percent of North Borneo's population according to the 1931 census, had declined sharply during the colonial period and bore the brunt of many of the public health issues facing the territory (Polunin \& Saunders, 1958, p. 1007; Jones, 1967; Colonial Reports: North Borneo, 1952, 1953). The colonial state saw little point in actively combatting such epidemics in the hinterland, opting instead to govern behaviour rather than health, medication and sanitation (Simmonds, 1944, p. 187). ${ }^{1}$ Profit-driven, and undermined by severe financial woes, the North Borneo Chartered Company saw these ostensibly unhealthy alcoholic practices as a threat to its plantation and resource-extraction economies, and ultimately the root cause of state-wide economic stagnation and political unrest. As a result, Murut depopulation accelerated at an alarming rate, and by the time the next census was recorded in 1951, the Murut population had decreased by 38.3 percent (Colonial Reports: North Borneo, 1952, 1953).

This article seeks to historicise the relationship between alcohol, disease and depopulation in British North Borneo, a colonial territory routinely undermined by administrative laxity, a wanton disdain for indigenous lives, and profit-minded, exploitative governance (Saunders, 2019 \& 2020). It does so by examining how in the early 1920s, shifts in the colonial plantation economy, growing patterns of internal migration, and rising mortality rates upended the status quo in indigenous agricultural communities. It builds upon extensive work on alcohol and empire, public health and colonial policy, and the relationships between colonialism and indigeneity, showing how the colonial state considered alcohol consumption an epidemic of devastating proportions. As a disease of the mind, perhaps, or a highly infectious behavioural affliction, fears of alcohol abuse preyed on the colonial psyche as a more pressing pestilence than exotic diseases and tropical epidemics. At times, fears over the spread of drunkenness and disorder purportedly threatened the very survival of the North Borneo Chartered Company's commercial enterprises, which depended on extensive indigenous and imported labour.

Importantly, examining the relationship between alcohol policy and public health helps cast light on issues of disease and mortality in the colonial tropics. Such issues are typically framed in terms of exotic tropical diseases - malaria, dengue fever and dysentery, and their effects upon colonial bodies - but the moralistic dimensions of

\footnotetext{
${ }^{1}$ Indeed, in colonial medical circles there were frequent criticisms of the apparent 'apathetic attitude of the native people toward sanitation and European medicine ... [and] the consequent lack of co-operation' (Simmonds, 1944, p. 187).
} 
eTropic 20.1 (2021) Special Issue: Pandemic, Plague, Pestilence and the Tropics

alcohol consumption cut to the core of colonial sensibility in a state driven by commercial enterprise. Why, then, did the purported threat of alcohol consumption gain precedence over more pressing tropical disease epidemics? Why were the effects of alcohol addiction and disease framed in economic rather than public health terms? What does this reveal about colonial governance more broadly? Were colonial attempts at governing alcohol consumption ultimately misguided? These interrogatives become even more salient when considering the contemporary COVID19 pandemic, in which Sabah has been affected disproportionately compared to wealthier states in Malaysia. As the events of the 1920s and 1930s show, effective governance and a clear understanding of the situation on the ground (rather than turning to scapegoats such as alcohol addiction) is necessary in order to deal with spiralling public health crises.

While a wealth of scholarship has been produced examining the role of disease, epidemiology and public health in Asia (Arnold, 1993; Anderson, 2006; Peckham, 2016) and that of alcohol, colonial policy and addiction in colonial contexts (see, for instance: Peters, 2002; Sasges, 2014; Warren, 2013), few studies have commented on the reported links between alcohol, disease and governance in Borneo and maritime Southeast Asia. Likewise, although scholars have written extensively on prohibition and temperance movements in the early twentieth century, much of this literature remains highly Western-centric, focusing primarily on the United States or North-western Europe (Butler et al., 2017, pp. 1-3). A key touchstone is the body of work focusing on colonial alcohol policy and local patterns of production and consumption across South Asia (Menon, 2015; Wald, 2018; Alagirisamy, 2019a) and Africa (Schler, 2002; Korieh, 2003). Similarly, recent studies examining temperance movements and race in both urban and plantation environments in colonial Southeast Asia have provided important interventions (Krishnan et al., 2014; Alagirisamy, 2019b). Despite this, tropical regions along the peripheries of empire such as Borneo remain neglected.

This article is structured into four subsections. Part one examines the role of alcohol addiction as a disease and lays out the relationship between colonial governance and local indigenous societies. Part two analyses how the sudden collapse in the availability of rice laid bare colonial assumptions about indigenous drinking. It argues that incomplete colonial knowledge of the Borneo interior gave rise to exaggerated assumptions and racial prejudice. The third part examines how colonial attempts to surveil the hinterland and extend their knowledge of indigenous society were connected to desires to maintain profitability for domestic shareholders in the metropole. The final part analyses colonial public health investigations. Although the state obtained more accurate demographic data by the early 1930s - which exposed the scale of indigenous suffering and depopulation - attempts to improve indigenous 
eTropic 20.1 (2021) Special Issue: Pandemic, Plague, Pestilence and the Tropics

public health were ultimately reflective of the grave inefficiency and unpreparedness of the chartered company state. Colonial theories and explanations of depopulation, especially concerning the ostensibly widespread nature of tapai addiction, remained in place until the late 1950s (Polunin, 1959). The legacies of this (and that of lax and ineffectual colonial governance more broadly) remain perceptible today. This is especially true when considering the fate of Sabah amidst the ongoing COVID-19 pandemic.

\section{Alcohol, Addiction and Disease: A Colonial Dilemma}

The links between addiction and disease have long been recognised in public health discourse (Ramalho, 2020). Despite being classified as a disease, sufferers of addiction continue to be stigmatised, marginalised and even reviled by health authorities and the public alike. Although addiction is endemic within all societies, its aetiology - and especially the language through which the disease is addressed remains tinged with stigma and misperception. As Linda Richter and Susan E. Foster argue, "when a health condition is thought to derive from bad behaviour, a character flaw, or a moral deficit", it elicits a different response than when it is "thought to derive from a genetic predisposition, a neurological disorder, or a medical disease" (2014, pp. 60-1). Katherine Pettus, for instance, traces the "modern concept and language" of addiction to the colonial-era opium trade and expansion of the British Empire, where colonial depictions of addiction were replete with racialised notions of "evil" and "abuse" (2019, pp. 197-203).

In British North Borneo, colonial stigmatisation of addiction even extended to cases where alcohol did not produce adverse behavioural or health issues. Sweeping claims and race-based generalisations emerged from rumour, hearsay and sporadic colonial visits to upland communities. Ostensible bad habits and nefarious practices were branded upon various ethnic and socio-economic groups by colonials. The colonial state, as the primary source of political power (and, as it would claim, also scientific knowledge and moral leadership) monopolised the epistemological parameters and definitions of addiction and vice (Copeland, 1935, pp. 1233-5). The complexity and heterogeneity of non-white societies in British North Borneo, as in British Malaya and the Dutch East Indies, elicited significant racial prejudice and oversimplified categorisations of indigenous societies and their cultures and customs. As Farish A. Noor writes, ethnic diversity in Malaya was frequently reduced in colonial discourse to three races that bore the "essential characteristics" of "idleness, criminality and drunkenness" (2016, p. 185). Similar categorisations were deployed by colonials in North Borneo, except that unlike in Malaya (where Malays were viewed as "idlers", Chinese as "thieves", and Indians as "drunkards") drunkenness was believed to primarily afflict indigenous Murut and Kadazandusun communities. 
eTropic 20.1 (2021) Special Issue: Pandemic, Plague, Pestilence and the Tropics

As in much of the Southeast Asian tropics during the early twentieth century, Chinese minorities in Borneo were classed as frequently addicted to opium and prone to gambling (Wong, 2004, p. 97). Similarly, by sheer association or proximity, many were deemed facilitators of vice. In William Somerset Maugham's 'Before the Party', for instance, the malaria-afflicted and alcoholic District Officer, Harold Bannon, manages to evade the attempts of his wife and the governing Resident to prohibit whisky by procuring it from "the Chinese", who were all too eager to make a sale (Maugham, [1922] 2000, p. 168). Brimming with all manner of (sometimes contraband) goods, such businesses were frequently deemed sources of illicit produce, and thus vectors of vice.

Indeed, as can be seen in these examples concerning colonials, agency and blame was not accorded upon the flawed District Officer, but rather upon the purveyor of the alcohol - in this case, the Chinese shopkeeper. Other ethnic groups fared little better, with many subjected to colonial scrutiny and condemnation over their alleged propensity for drink, even if their habits were no more indulgent or celebratory than their colonial overlords. Labourers at rubber plantations, though at times permitted by the British North Borneo Company to gamble, drink and smoke opium as a way of keeping them from "being idle" and preventing unrest, were also classified as frequent addicts and drunkards (Wong, 2004, pp. 97-9). Many colonials feared that indigenous labourers, too, who were employed at colonial plantations en masse in the early twentieth century, would bring with them their unwanted drinking habits (De Silva, 2009, pp. 61-2). Like mosquitos, rats and other pestilential animals that spread disease, colonial authorities appeared to cast the indigenous worker as a vector of alcohol and drunkenness.

Yet for centuries, alcohol consumption had been an important aspect of life for many indigenous Kadazandusun and Murut communities across Borneo. The distilling of indigenous drinks such as tapai [rice beer], tuak [fermented palm sap] and arak [sugar cane spirit] were firmly rooted in cultural and culinary traditions. ${ }^{2}$ Distillation, fermentation and consumption served as ties that bound many rural villages together, especially in times of celebration, reunion and mourning (Phelan, 2001, p. 35). Alcohol was also a social arena where women freely participated and played a central role in its production and consumption (Whitehouse, 1978, p. 28-30). For generations, tropical liquors formed a solid socio-cultural foundation upon which indigenous society functioned. Yet as colonial governance penetrated further into the Bornean environment in the 1920 s and 1930s, such practices were increasingly scrutinised as

\footnotetext{
${ }^{2}$ Tapai is very popular in across Borneo and parts of Indonesia, while arak (arrack) can be found across Southeast Asia and the Indian subcontinent. Tuak, in its many forms, is also widespread. In southern India it is referred to as toddy, having similarly been fermented from palm sap (neera).
} 
eTropic 20.1 (2021) Special Issue: Pandemic, Plague, Pestilence and the Tropics

harbingers of disease. Indeed, while colonial drinks such as gin pahits, whisky sodas and quinine-laden tonics were deemed vital healthy reprieves from the torrid environment, "native" liquors were classed as harmful.

By the 1920s, indigenous alcohol consumption was increasingly decried in colonial directives as problematic, as were other aspects of indigenous living such as the physical kampong [village] itself. In the colonial period, the indigenous built environment was deemed a diseased space; an affirmation brought on by allegations of poor sanitation, shoddy construction and contamination from farm animals and pests (Simmons et. al., 1944, p. 387). Indeed, as Robert L. Winzeler points out, as late as the 1950s there were some social anthropologists who continued to view the kampong, and "longhouse society" in general, as "verging on anarchy" (2004, p. 9).

In the colonial period, as in contemporary Sabah today, healthcare infrastructure in North Borneo frequently lagged behind wealthier territories in the region, particularly in neighbouring Malaya. Shortfalls in public health mirrored the wider economic stagnation that characterised semi-autonomous chartered company rule (Massey, 2006, p. 58).

In today's context, where governments the world over have sought to manage the spiralling COVID-19 pandemic, efforts to control public behaviour, activities and movement have taken precedence. Lockdowns, quarantines, social distancing, maskwearing and in some cases even alcohol bans, have been utilised by disease-weary states in attempts to control public behaviour and limit the spread of the pandemic (Lim, 2020; Berger, 2020). The current limited and fraught availability of vaccines and the inability to effectively treat sufferers is likely to persist even after preventative inoculation becomes readily available, especially in poorer regions across the developing world, which face difficulties in securing vaccine orders.

Indeed, this is replicated within national and sub-national contexts, where poorer regions (that have historically been considered as more prone to alcohol abuse) face shortages in medical equipment and personnel relative to wealthier metropolitan centres. Within Malaysia, Sabah has been hit the hardest: in late October 2020, Sabah's cumulative cases of COVID-19 had amounted to over $46 \%$ of Malaysia's total, despite the state constituting only $12 \%$ of the country's population. The trend has subsequently worsened, with $90 \%$ of Malaysia's "sporadic cases" (defined by the WHO as "tip-of-the-iceberg-cases", independent of known clusters) occurring in Sabah (Carruthers, 2020, p.4). The pandemic has had further unforeseen consequences, with, for instance, polio vaccination programmes in Sabah being interrupted by the spread of coronavirus (WHO 2020). 
eTropic 20.1 (2021) Special Issue: Pandemic, Plague, Pestilence and the Tropics

Similarly, in the 1920s and 1930s, fears of alcohol dependency preyed on the colonial psyche as a cause of further ill health and social decay. These views aligned with contemporaneous colonialist perceptions towards indigenous society as inherently flawed, vulnerable and in need of guidance. Such assumptions also reflected ongoing temperance and prohibition movements in the West (Yeomans, 2011, pp. 38-40). Alcohol was thus perceived as a placing undue strain on an already weak healthcare system. Many colonials questioned how tropical diseases such as malaria and dengue fever could be combatted, when an even more pernicious affliction in the form of alcohol and its accompanying vices was seen to be sweeping society. Understanding the legacies of past failures in colonial public health policy in British North Borneo therefore provides much-needed context for these contemporary pressures. Indeed, this achieves particular salience today, where in Sabah "traditional alcohol production and consumption [remains] ... interwoven into Bornean culture" (Pang et. al., 2020, p. 130). Only recently, in the late 2010 s, have government efforts to ascertain alcohol "use disorders" amongst rural Kadazandusun communities become more culturally, linguistically and "ethnically sensitive", whilst also claiming to achieve greater statistical reliability (Pang et. al., 2020, pp. 138-9). Despite this, colonial-era assumptions concerning indigenous alcohol dependency have cast a long shadow and continue to shape perceptions of indigenous life today.

\section{Demographic Shifts and Impending Famine}

Similar uncertainties were observable in North Borneo in the 1920s and 1930s. A perfect storm of economic reconfiguration, crop failure, spiralling disease, rising mortality and increasing demographic movement led to a deterioration in the quality of life for many of the colony's poor and disenfranchised. The widespread unavailability of medical equipment, infrastructure and personnel, coupled with the state's unwillingness to go out of its way to provide relief and aid, exacerbated conditions.

Prior to 1915, the territory was shaken by frequent conflicts and so-called "rebellions" (Tregonning, 1965, p. 199). During the early colonial period between the 1880s and early 1910s, the coastal-bound and politically vulnerable North Borneo Chartered Company waged numerous punitive expeditions, and later even wars, against indigenous pangerans [princes] and chiefs who were unwilling to relinquish their autonomy. It was only in 1915 that anti-colonial resistance was quashed, following the defeat of Ontoros Antanum and other Murut "rebels" (who are now recognised as freedom fighters) in the Rundum District in the southern highlands (Radius, 2012). But with increased political stability came greater colonial administrative penetration into the Bornean hinterlands in the 1920s and 1930s. 
eTropic 20.1 (2021) Special Issue: Pandemic, Plague, Pestilence and the Tropics

This heightened colonial-indigenous contact contributed to major economic shifts and demographic changes by the early 1920s. Remote indigenous society suffered disproportionately, experiencing major socio-economic dislocation. Once-prosperous kampongs declined rapidly due to a loss of young workers. Able-bodied men and women were increasingly drawn to colonial rubber plantations along the coastal lowlands, where they found themselves bound by strict indentures and debt bondage. This contributed to a widening labour shortage amongst indigenous rice-cultivation systems (Massey, 2006, p. 240). Stephen Holley argued that rubber plantations "disturbed kampong life": adults would "trek to an estate to work ... leaving the old and infirm and their children to fend for themselves" (2004, p. 67).

Alongside this decline in the available workforce amongst indigenous agrarian communities, a major transnational rice crisis unfolded across Southeast Asia between 1919-21. The rapid proliferation of rubber, tobacco, tea and sugar crops in the early twentieth century contributed to stark demographic and employment shifts in colonial North Borneo, as well as Malaya, Sumatra, the Philippines and Ceylon. In these places, immigrant populations were rising, and rampant internal migration increasingly drew locals towards the coasts (Kratoska, 1990, pp. 115-6). In 1919, rice exports from Saigon in French Indochina and other rice-rich hubs plummeted by almost 50 percent, causing prices to double (Cherry, 2019, pp. 94-5). Matters worsened when it became clear that local production would not be able to compensate for import deficits, causing further speculative buying, soaring prices and dwindling reserves (Kratoska, 1990, p. 116).

In addition to these demographic and socio-economic transformations, worsening public health conditions wreaked havoc among vulnerable rural Murut communities (Polunin \& Saunders, 1958). The chartered company's Court of Directors in London was cognisant of proliferating ill health and its projected impact upon the territory's indigenous minorities as early as 1922, but did little to ameliorate the situation (State of North Borneo Official Gazette, 1922, p. 38). As lan Black argues, the British North Borneo Company sought "to rule at minimum cost" (1983, p. 32). The colonial government asserted that indigenous ill health, famine and population decline were caused by poor agricultural practices, laziness and drunkenness - each being, so it was claimed, the product of behavioural and moral defect. Colonial critiques frequently commented on the purported inefficiency of swidden techniques, as well as the alleged propensity to utilise vital rice reserves for the brewing of tapai (Cook, [1924] 2007, p. 23; Rutter, [1929] 1985, p. 86; Woolley, [1936] 2004, p. 55; Williams, 1965, p. 68-9). But these colonial castigations derived more from disdain and misunderstanding than from evidence or fact. As illustrated by Figure 1, for example, many indigenous Kadazandusun and Murut communities were capable agriculturalists. Although slash and burn agriculture was inherently inefficient - and common amongst rural 
eTropic 20.1 (2021) Special Issue: Pandemic, Plague, Pestilence and the Tropics

smallholdings where land was never in short supply - it alone did not account for the territory's food shortages (Dove, 1993, p. 137).

Likewise, the volume of rice utilised for tapai production had little direct effect upon available food reserves, as tapai formed a major source of nutrition and calorific intake (Merican \& Yeoh, 2004, p. 247). Across much of Borneo, tapai recipes ranged from rice beer, to hearty soups or broths with rice grains intact, to firm alcoholic rice patties or cakes (tapai pulut [fermented sticky rice]). Indeed, as the fermentation of rice into alcoholic foodstuffs and drink "prevents ... spoilage and pathogenic microorganisms", tapai (and its regional variants) was a valuable dietary component for many Southeast Asian communities (Haard et. al., 1999). Furthermore, as shown by Ganesan et. al. (2020), traditional food practices continue to "secure and safeguard community indigeneity" amongst Borneo's indigenous groups. Alcohol - as nutritious, calorific tapai pulut or as a beverage - had for generations been firmly rooted in Murut (and indeed also Kadazandusun) societies.

Figure 1: Padi [rice] farmers in North Borneo tend their crop.

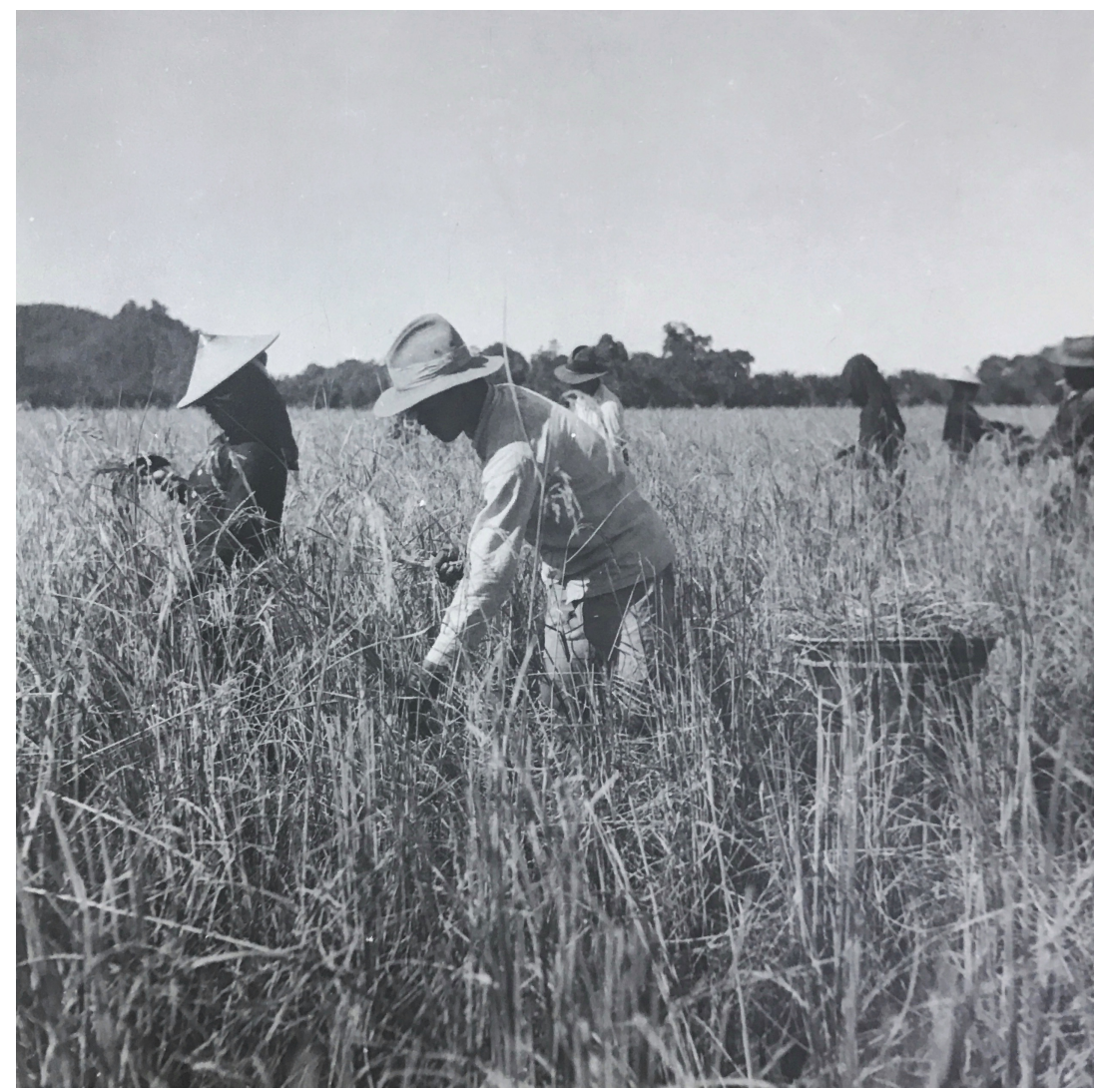

By the 1930s more stable food production had been achieved. Source: Woolley 1937; The National Archives CO 874/463. 
eTropic 20.1 (2021) Special Issue: Pandemic, Plague, Pestilence and the Tropics

Contrary to colonial assumptions, Murut folk songs and oral tradition from the 1920 s indicated that while tapai consumption was important for leisure, brewing actually ceased in times of economic hardship and famine. In one such song, transcribed in 1929, the singer encourages their "brethren" to drink on a special occasion, before lamenting that they "seldom make tapar" in these times due to being "poor" and "needy".

Ho ye, our brethren,

Drink ye the tapai,

Taste ye the brewing!

Yet drink ye freely.

Unlike our neighbours

We seldom make tapai:

We of a truth now

Are poor men and needy.

(Rutter, 1929, p. 115)

This anecdote contradicts colonial claims that even the poorest of Murut communities were drinking themselves into starvation and depopulation. Although lacking direct evidence, the colonial government continued to assert that the rice that was sporadically produced by indigenous smallholders was used for the brewing of tapai and other alcoholic beverages (Macaskie to Government Secretary, 1922, pp. 78-80). In colonial eyes, as well as being a drain on vital food reserves, alcohol consumption - often equated to abuse - was the main cause of lawlessness, idleness and sickness.

\section{Living "in a permanent state of intoxication"?}

Colonial attitudes concerning indigenous Murut alcohol consumption, rising ill health and depopulation derived from an increasing number of administrative and surveillance expeditions undertaken in the 1920s and 1930s (Kaur, 1994). This increased colonial surveillance - and thus greater colonial penetration into the hinterland - shaped the government's assumptions surrounding local drinking patterns, even if they had little grounding in evidence or fact. Amarjit Kaur (1994, p. 8) has termed this a form of "government by expedition", whereby colonial authorities sought to project influence in far-flung regions that would otherwise go months, if not years, without interaction with the state.

Ironically, as colonial visits to remote communities were often occasions in which alcohol would be served, officials developed a warped view of indigenous alcohol consumption that complemented already-entrenched bias (Moo-Tan, 2018, p. 129, 155). Indeed, this contributed to a cognitive dissonance within administrative circles 
eTropic 20.1 (2021) Special Issue: Pandemic, Plague, Pestilence and the Tropics

that kampongs were always spaces of hedonism and drunken revelry, simply because that is what was often witnessed, documented and in turn disseminated through colonial reportage and memoranda.

Rather than being a daily habit, however, alcohol consumption for many Murut communities was reserved for special occasions or festivities. One Murut folk song from 1927, for instance, was sung as "an invitation to drink ... on [the] arrival of a chief or party of well-known warriors", a significant event:

Come, brothers,

Shame will fall on you:

Ye are slow to drink.

Follow in quick succession at the jar,

All ye that are in the house.

(Woolley, 1927, p. 366).

In peacetime, and on the back of increased colonial penetration into Borneo's interior in the 1910s and 1920s, such traditions were even extended to welcome colonial officers as a show of goodwill. Another song, again from 1927, reveals how colonial inspections even elicited enthusiasm:

Not daily, not every day is it

That strangers visit, that men come to us.

A white padi-bird, a kenawai [European visitor],

Whilst many of us are here, has come to us.

(Woolley, 1927, p. 368-9).

Ironically, however, such colonial visits - serving as acts of surveillance or administrative function - were neither beneficial for the host communities nor viewed positively by officials. Tax collections were the bane of many vulnerable and cashstrapped societies across North Borneo (Massey, 2006, p. 249). Without ready access to money, and unable to produce marketable cash crops without neglecting rice cultivation, many Kadazandusun and Murut were condemned as lazy and prone to inebriation. As portrayed by one satirical poem that was published in The British North Borneo Herald in 1928, tax payments were reportedly only made willingly when tapai could be guaranteed afterwards:

Oh thou wert constant in the hills, your vigilance never lax;

Collecting duits [coins], the copper duits that pay our tax.

The duits were weighed, the tax is paid, we've journeyed from afar,

Hurrah! Hurrah! For Poll Tax, and for the tapai jar.

(“Tenom Notes", 1928, p. 93). 
eTropic 20.1 (2021) Special Issue: Pandemic, Plague, Pestilence and the Tropics

The indigenous drinker, parodied in government discourse as pliable, naïve and perhaps foolish, was a source of amusement to colonials. But this amusement concerning alcohol consumption was invariably accompanied by scorn and disdain that was, by the late 1920s, etched into the very fabric of colonial administration and society. Over time, this formed a discourse of "poverty propaganda", to borrow Tracy Shildrick's term, which "ensure[d] that myths and false pronouncements" about the poor and disenfranchised - in this case, Murut ethnic minorities - were disseminated widely. This resulted in a condition that was simultaneously "normalised" and yet "demonised" (Shildrick, 2018, p. 2).

The categorisation of indigenous societies as naïve, sickly and yet inherently menacing was part of a broader shift in the colonial psyche. Administrative confidence grew in tandem with more entrenched political authority and thus a greater interference in indigenous lives. What was once considered an innocent quirk of so-called "native" society increasingly became a source of concern and frustration for the colonial government, which sought to govern with as little financial outlay as possible (Black, 1983 , p. 32). These shifts were further encapsulated by the official view amongst company bureaucrats that the colony had by 1922 transitioned from a tenuous "pioneer phase" to an apparently more stable "stage of development" ('Annual Report on the West Coast Residency for 1922', 1922, p. 373). In such an era shaped by notions of "progress" and the civilising mission, "development" was primarily viewed in terms of a capacity for profit, but also through the state's self-assumed (though somewhat reluctant) role as the custodian of indigenous lives. Indeed, where in previous years there was little direct contact with Borneo's forested and mountainous interior, by the 1920s it was increasingly becoming a site of governance.

Although the pacification of so-called "rebels" in 1915 gave rise to a heady colonial confidence in the colonial project, domestic shareholders and the company's Court of Directors in London remained in constant need of (re)assurance. For the colonial government, indigenous ill health could not be publicly seen as deriving from colonial fault: new explanations were required to justify economic stagnation and low dividends. Colonial authorities were quick to cast the blame upon rampant alcoholism and ineffective rice allocation. Indeed, just as North Borneo's populous urban ports were more frequently the sites of epidemic outbreaks of cholera, bubonic plague and influenza than remote upriver settlements, so too was alcohol consumption more a feature of prosperous (particularly colonial) coastal regions than it was amongst interior kampongs. As one European traveller penned in earlier years: "as they were oftener intoxicated", the "natives" of the coastal lowlands were surely "more comfortable and better off" than their upland neighbours because they had enough rice reserves remaining to brew tapai (Hanitsch, 1900, p. 63). Such explanations would not sit well with wavering shareholders, however, who sought evidence that colonial 
eTropic 20.1 (2021) Special Issue: Pandemic, Plague, Pestilence and the Tropics

settlements were healthier, more orderly (and thus more productive) spaces than Borneo's torrid jungle.

The North Borneo Chartered Company's administrators played an active role in perpetuating negative perceptions of indigenous society among domestic audiences in Britain. Their work contributed to the growth of critiques (a sort of "poverty propaganda", perhaps) of indigenous living that straddled fact and fiction. Oscar Cook, District Officer for the colonial town of Semporna on the far east coast, for instance, wrote scathingly that Muruts were living "in a permanent state of intoxication" ([1924] 2007 , p. 23). Upon retiring home to Britain, Cook contributed to a growing corpus of research produced by so-called "scholar administrators" that configured much of the orthodox academic and popular understandings of Borneo for years to come (Wong, 2004 , p. 131-4). His descriptions of "native" drinking practices painted a picture of a society marred by rampant alcoholism and self-destruction:

Tapai drinking has always been a source of worry to the Government, for not only do the natives consume a very large portion of their potential food-crop in its manufacture, but many senseless crimes are committed by them when under its influence. Also, to a certain extent, it accounts for the high rate of infantile mortality, since fond mothers frequently give babies at their breasts a long suck at the straw, with a remark such as, "Poor baby, of course he wants his tapai too!" (Cook [1924] 2007, p. 23).

Another retired administrator-turned-writer, Owen Rutter, echoed these criticisms. Murut were "neither skilled nor prudent farmers", claimed Rutter in 1929. "So much [rice] is used for the manufacture of tapai" that supplementary foodstuffs, such as tapioca, corn, yam and cassava, were reportedly required to keep communities afloat (Rutter, [1929] 1985, p. 86, 93). There was a feeling among European plantation bosses, too, that bad habits were spreading from the interior to the workplace, where productivity was enforced by the meting out of violent punishment and the withholding of wages. One estate manager, for instance, claimed that after the indigenous labourers returned to the rubber plantation following "a recent [rice] harvest it was difficult to find a sober man among them for weeks at a time" (De Silva, 2009, pp. 612).

In fact, even under the watchful gaze of colonial supervisors, fears of alcohol consumption amongst indigenous workers continued to prey on colonial anxieties. On colonial surveillance trips across North Borneo's remoter regions, alcohol consumption was frequently blamed for delays and disturbances. George Cathcart Woolley, Resident of the Interior, and later Commissioner of Lands, bemoaned in his 
eTropic 20.1 (2021) Special Issue: Pandemic, Plague, Pestilence and the Tropics

diary in the early 1920s that he was often held up by so-called "coolies" who were too hungover to work, having been up all night drinking jars of tapai (Moo-Tan, 2018, p. 434). During an inspection of Kampong Benoni, a small township to the south of the major west coast trading port of Jesselton, ${ }^{3}$ Woolley recorded that he and his team of "coolies" stumbled upon an illicit arak still that was hidden "under a shed by the riverbank". Curious, Woolley stopped to sample the local moonshine, which he described as "hot: sweet, but not pleasant"; the liquor apparently having been spoiled by Borneo's tropical climate (Wong \& Moo-Tan, 2015, p. 296). On another occasion, having sampled some local tapai from Kampong Tarawi, in the Penampang District, he described it as being warm, having "a musty nondescript" flavour, although likely "very mild in strength" (Wong \& Moo-Tan, 2015, p. 165). These efforts by colonial administrators to surveil, sample, and later categorise indigenous alcohol usage, were part of a broader process linked to the acquisition of knowledge and the laying down of colonial rule (Wong, 2009, pp. 90-1).

\section{Colonial Medical Investigations and Legacies of Administrative Neglect}

Scientific missions and ethnographic projects in the 1920s and 1930s increasingly supported the government's claims that rampant ill health and depopulation were products of behavioural defect and addiction. While census data collected every decade since 1891 revealed that the colony's overall population was increasing, many Murut kampong communities were declining sharply (Jones, 1967). The scale of depopulation among vulnerable indigenous ethnic groups was not fully realised until 1931, when more accurate census data revealed the scale of low birth rates and infantile mortality (Singh, 2011, p. 27). Between 1921 and 1931, the Murut population plummeted by 19.5 percent, and between 1931 and 1951, numbers decreased by an additional 23.6 percent (Jones, 1967, p. 133). In previous years, the government had conceded that "no great reliance" could be placed upon official statistics and data collection measures. Natality data, in particular, was considered "far from accurate" (The British North Borneo (Chartered) Company, 1929, p. 32). According to official explanations, there was no accurate way of recording the frequency of births and deaths in the intervening years between the official census ('Annual Report on the West Coast Residency for 1921', 1921: 220). This was largely due to the fact that censuses in North Borneo "were taken exceptionally cheaply by any standards", costing as little as 1,500 Malayan Dollars (Jones [1966] 2007, pp. 18-9). ${ }^{4}$

Although colonial knowledge of rural living conditions remained vague, assumptions surrounding supposed alcohol dependency continued to shape policy. Following the

\footnotetext{
3 Jesselton is now Kota Kinabalu, Sabah's administrative capital.

${ }^{4}$ Census costs in North Borneo between 1911-1931 ranged from as little as $\$ 1,500-\$ 7,700$. After the territory became a crown colony in 1946, census costs has risen to $\$ 139,000$ in 1960 (Jones [1966] 2007, pp. 18-9).
} 
eTropic 20.1 (2021) Special Issue: Pandemic, Plague, Pestilence and the Tropics

1931 census, the British North Borneo Company commissioned an investigation into indigenous health and the so-called threat of "racial extinction" in 1933 (Copeland, 1935). Headed by A. J. Copeland, District Surgeon for the Beaufort and Interior Residencies, the investigation sought to ascertain medical conditions and provide recommendations on how best to ameliorate declining indigenous public health.

Figure 2: "A small dispensary, with dressers and carrier".

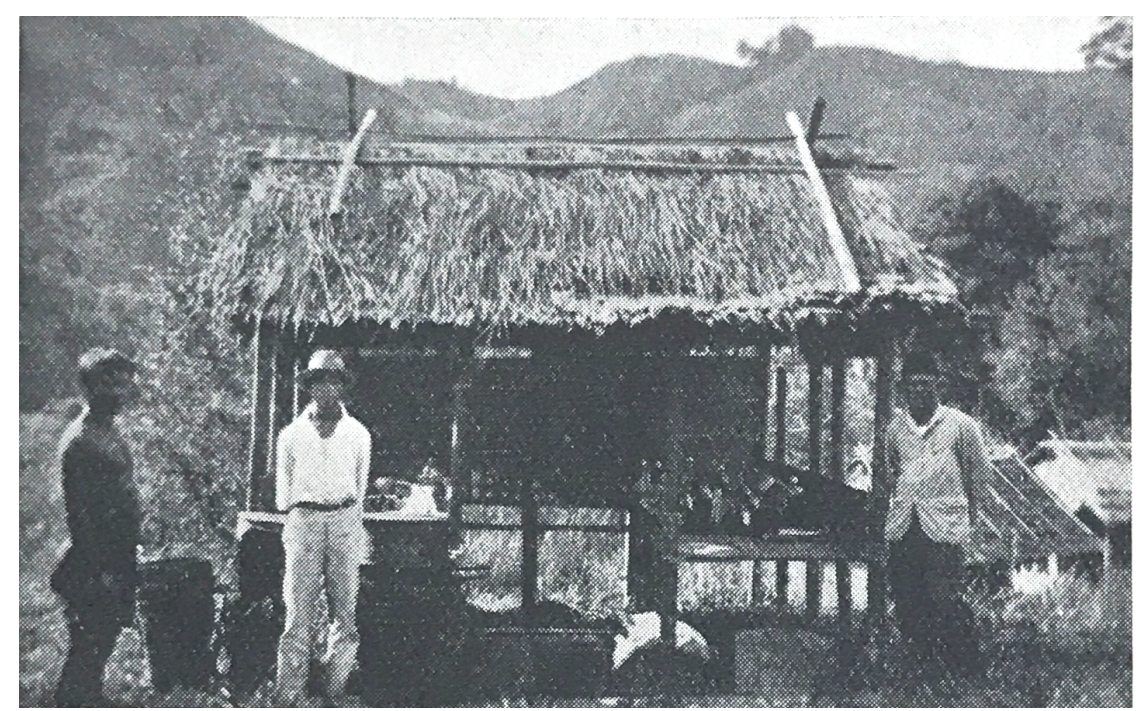

Source: Copeland 1935, p. 1235; The National Archives CO 531/25/8.

Figure 3: "A large temporary dispensary in process of erection".

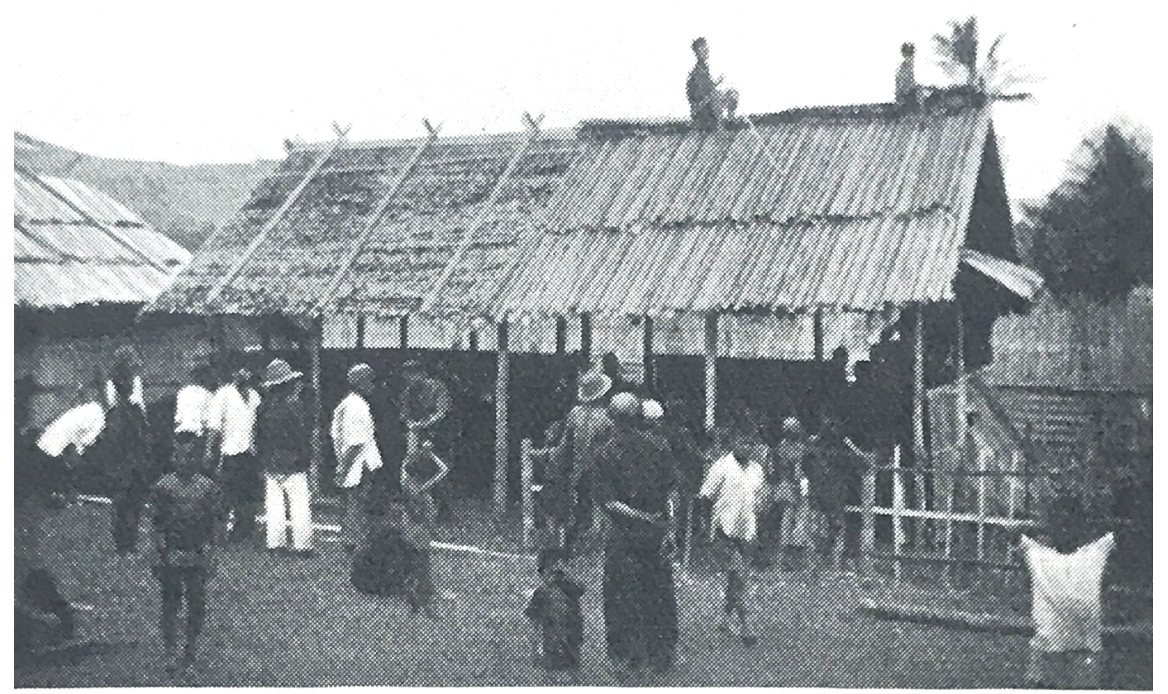

Source: Copeland 1935, p. 1235; The National Archives CO 531/25/8. 
eTropic 20.1 (2021) Special Issue: Pandemic, Plague, Pestilence and the Tropics

Throughout much of the 1930s, government healthcare and public health infrastructure remained notoriously inadequate. In the Beaufort and Interior Residencies alone (which constituted approximately one quarter of the colony's total land area) the medical staff consisted of a mere "six dressers" to deal with a population of 56,000 people (Copeland, 1935, p. 1233). Unsurprisingly, Copeland's report was highly incriminating and came as a shock to many metropolitan observers in Britain. It outlined the grave state of indigenous health in the colonial territory and painted a bleak picture of chartered company governance. Long afflicted by dirt-borne and infectious diseases, recent outbreaks of influenza and measles were described as the "last straws to break the camel's back" (Copeland, 1935, p. 1233). "Extinction", it was claimed, was a real likelihood.

Although these diseases were considered the main causes of depopulation, colonials still maintained their long-standing aversion towards indigenous behaviour and living conditions. Poor sanitation, communal long houses and propensity for drink, it was believed, were to blame for rampant disease. Copeland criticised the indigenous built environment as a major factor in causing high mortality rates. He derided Murut and Kadazandusun villages as being sites of contagion and depravity, detailing how "they live in primitive bamboo houses roofed with native thatch or attap ... a dark and gloomy dwelling". Copeland reiterated the age-old colonial criticisms of indigenous drinking practices, arguing that on many occasions it was difficult to even provide medical aid or "collect patients" because "villagers were either engaged in husbandry or in communal drinking parties". These wild, indulgent "drinking parties", he lambasted, lasted "day and night, until the supply [of tapar] is exhausted" (Copeland, 1935, pp. 1233-5).

Some official responses to Copeland's report in 1935 revealed a crude disregard for indigenous lives. H. R. Cowell, a company administrator, expressed relief that British North Borneo was ruled by a "commercial company" and not an official crown colony government: a semi-private commercial enterprise such as the North Borneo Chartered Company, he argued, was subject to different legal, political and moral obligations (Cowell, 1935). Responding to the dire state of affairs of indigenous health, Cowell stated that:

In any of the Colonies a criticism of this sort ... would bring a storm of Parliamentary questions about our ears. A commercial company is not expected to display so high a standard of social conscience. They must not kill; but need not strive consciously to keep alive. (Cowell, 1935) 
eTropic 20.1 (2021) Special Issue: Pandemic, Plague, Pestilence and the Tropics

Colonials such as H. R. Cowell exhibited a wanton disregard for indigenous lives. In his view, indigenous deaths were merely statistics, and their lives merely coincidental happenings on an island that supposedly existed for the extraction of commodities for colonial benefit and shareholder enrichment.

Although the report was scathing of the state of affairs, its recommendations ultimately reflected the wider chartered company context under which it was commissioned. In his conclusion, Copeland recommended simply that to combat malaria and other tropical diseases, urgent supplies of quinine were required (1935, pp. 1239). ${ }^{5}$ Ultimately, medical reports such as these represented a weak attempt by the North Borneo Chartered Company to ascertain living conditions amongst its subjects. Copeland likely understood that systemic change, under the company system, was unlikely to elicit backing amongst domestic shareholders and bureaucrats. As such, in the years that followed, only incremental change was enacted. While in 1933 there were only six healthcare workers in the Beaufort and Interior Residencies, by 1937 the number had increased to 54, comprising seven nurses, two midwives and 45 "dressers" who were under the command of colonial medical officers (Simmons et. al., 1944, p. 387). Despite this increase, medical offerings in the remote jungle and mountain regions remained woefully inadequate compared to the wealthier port cities of Sandakan and Jesselton.

The legacies of this colonial paradigm lasted well into the 1950s, and even beyond eventual decolonisation in 1963. It was only in 1959 that ethnographers and medical officials decided that alcohol was ultimately not to blame for depopulation and ill health among Murut ethnic minorities. Ivan Polunin, medical doctor and filmmaker, reported in 1959 that although the Murut "have the reputation of drinking large quantities of alcohol", this was "probably less" than "in some European countries" (1959, p. 315, 320). In fact, Polunin was unusually perceptive when it came to understanding how colonials formed and perpetuated biased knowledge of indigenous health. "With regard to the effects of alcohol", wrote Polunin, "it is especially dangerous to draw conclusions from inadequate data in a field where prejudices are rife" (1959, pp. 325$6)$.

Colonial prejudice thus played a key role in the creation, and subsequent perpetuation, of explanations for indigenous ill health in North Borneo. Alcohol entered the colonial psyche as a pernicious yet eerily familiar vice. It became a convenient explanation for rising mortality, low natality and widespread afflictions of infectious diseases across the entire territory, as well as instances of disorder and criminality. The ostensible moral and behavioural faults of the Murut in particular, though ultimately fictitious and

\footnotetext{
${ }^{5}$ Copeland detailed that some 22,000 people were in urgent need of quinine, and that current annual distribution was far too little, amounting to less than 23 kilograms in total for the Beaufort and Interior Residencies.
} 
eTropic 20.1 (2021) Special Issue: Pandemic, Plague, Pestilence and the Tropics

exaggeratory, provided a useful means for colonials to absolve themselves of administrative neglect and disinterest, while continuing to reap dividends and profits for metropolitan shareholders. It was only after the Second World War, in the final years before decolonisation and merger with the Federation of Malaya, that serious consideration was given to ameliorating the lives of North Borneo's deprived and disenfranchised rural poor.

\section{Alcohol's Afterlives}

This article has explored the impact of alcohol in colonial governance and public health in British North Borneo, a colony along the periphery of empire in the early twentieth century. It has shown that, rather than being "in a permanent state of intoxication" (Cook [1924] 2007, p. 23), in which kampongs were alleged to frequently devolve into a "frightful pandemonium" (Harrisson [1938, reprint] 1988, p. 80), claims of indigenous alcohol abuse were used as convenient excuses for the lax and profit-minded British North Borneo Company.

Specifically, this article has argued that the island of Borneo, which was frequently cast in colonial imaginaries as an inherently unhealthy and ungovernable tropical environment, became a space in which colonialism could operate in an unchecked vacuum. In this sense, the only real pressures exerted on the North Borneo Chartered Company government (especially after 1915) were the necessities to meet the metropole's demands for profit and to combat economic stagnation. In marked contrast, indigenous public health, as well as education services and wider social infrastructure which had long been left by the wayside, were further worsened by colonial disinterest, inaccurate census data and the inherent difficulties posed by geographic distance and economic dislocation.

Through the analysis of Murut folk and oral traditions, it is contended that the consumption of indigenous alcohols such as tapai were an innocuous feature of local culture. This is contrary to orthodox assumptions, which alleged that communities facing famine would waste vital foodstuffs in the pursuit of alcohol brewing and hedonistic drunkenness. By linking to wider discourses on Anglo-American and Northwestern European temperance and prohibition movements, this article has argued that colonial policy was anchored to growing anxieties in the West that derived from the moral and religious concerns surrounding alcohol in the 1920s and 1930s. Indeed, while colonial lives in the tropics were awash with liquor and alcohol dependency ranging from the anti-malarial properties of quinine administered as gin and tonics, to the ill health brought on by alcoholism - colonials sought to paint a picture of respectability and superiority. And in this process, based in rumour and hearsay, 
eTropic 20.1 (2021) Special Issue: Pandemic, Plague, Pestilence and the Tropics

colonials instead cast alcohol addiction as afflicting the colony's indigenous peoples, especially those of the rural, poorer regions.

This article has furthermore shown that the desires to surveil, and in turn take control of the epistemological parameters of so-called alcohol abuse, was a core component of the colonial state's attempts to leverage authority. Part one of this article introduced colonial desires to govern behaviour rather than disease by showing how alleged alcoholism and instances of ostensibly poor conduct amongst indigenous society were used to absolve colonial governance. Part two explored the development of ontological and epistemological anxieties surrounding governance in a financially tenuous, though increasingly politically entrenched, colonial state. It revealed how anxieties over productivity and profit, alongside racist tropes concerning indigenous society, gave rise to exaggerated assumptions about the relationship between alcohol and ill health. Part three turned to colonial attempts to surveil the densely rivered and forested hinterland, where desires to maintain profitability for shareholders resulted in crude and lax medical policies. The final section focused on the laggard colonial responses to widespread ill health and depopulation by showing how, even following the publication of highly incriminating reports about colonial governance, some officials maintained their explicit, unconscionable aversion to helping marginalised Murut communities. The feeling that the North Borneo Chartered Company "need not strive to consciously keep alive" characterised semi-autonomous commercial governance in the tropics: simultaneously a proving ground for colonial administration, and a space where old and outdated colonial habits seldom changed. The legacies of widespread inequalities in public health resources and infrastructure - relative to wealthier and better-connected urban centres - are again perceptible as Sabah stands to be affected disproportionately amidst the ongoing COVID-19 pandemic. 
eTropic 20.1 (2021) Special Issue: Pandemic, Plague, Pestilence and the Tropics

\section{References}

Alagirisamy, D. (2019a). The Problem With Neera: The (Un)making of a National Drink in Late Colonial India. The Indian Economic and Social History Review, 56(1), 1-21. https://doi.org/10.1177\%2F0019464618816828

Alagirisamy, D. (2019b). Toddy, Race, and Urban Space in Colonial Singapore, 1900-59. Modern Asian Studies, 53(5), 1675-99. https://doi.org/10.1017/S0026749X1700083X

Anderson, W. (2006). Colonial Pathologies: American Tropical Medicine, Race, and Hygiene in the Philippines. Duke University Press.

Arnold, D. (1993). Colonizing the Body: State Medicine and Epidemic Disease in NineteenthCentury India. University of California Press.

Berger, M. (2020, 29 July). These countries are banning alcohol or closing bars in response to coronavirus surges. The Washington Post. (Accessed 7 November 2020). https://www.washingtonpost.com/world/2020/07/29/these-countries-are-banningalcohol-or-closing-bars-response-coronavirus-surges/

Black, I. (1983). A Gambling Style of Government: The Establishment of the Chartered Company's Rule in Sabah, 1878-1915. Oxford University Press.

Butler, S., Elmeland, K., Nicholls, J., \& Thom, B. (Eds.). (2017). Alcohol, Power and Public Health: A Comparative Study of Alcohol Policy. Routledge.

Carruthers, A. M. (2020). Movement Control and Migration in Sabah in the Time of COVID19. ISEAS Perspective, 135, 1-11. https://www.iseas.edu.sg/wpcontent/uploads/2020/11/ISEAS Perspective 2020 135.pdf

Cherry, H. (2019). Down and Out in Saigon: Stories of the Poor in a Colonial City. Yale University Press.

Colonial Reports: North Borneo, 1952. (1953). Her Majesty's Stationary Office.

Cook, O. [1924, reprint] (2007). Borneo: The Stealer of Hearts. Opus Publications.

Copeland, A. J. (1935). The Muruts of North Borneo: Malaria and Racial Extinction. The Lancet, 225(5830) 1233-9. https://doi.org/10.1016/S0140-6736(01)12582-1

Cowell, H. R. (1935, 17 August). [Statement]. (Colonial Office (CO) 531/25/8). The National Archives, UK (TNA).

De Silva, M. (2009). Javanese Indentured Labourers in British North Borneo, 1914-1932. [PhD dissertation, School of Oriental and African Studies, University of London].

Dove, M. R. (1993). Smallholder Rubber and Swidden Agriculture in Borneo: A Sustainable Adaptation to the Ecology and Economy of the Tropical Forest. Economic Botany, 47(2), 136-47. https://doi.org/10.1007/BF02862016

Ganesan, K., Govindasamy, A. R., Wong, J. K. L., Rahman, S. A., Aguol, K. A., Hashim, J., \& Bala, B. (2020). Environmental Challenges and Traditional Food Practices: The Indigenous Lundayeh of Long Pasia, Sabah, Borneo. eTropic: Electronic Journal of Studies in the Tropics, 19(1), 200-222. http://dx.doi.org/10.25120/etropic. 19.1.2020.3734

Haard, N. F. (1999). Fermented Cereals: A Global Perspective. Food and Agricultural Organisation of the United Nations.

Handbook of the State of North Borneo. (1929). The British North Borneo (Chartered) Company.

Hanitsch, R. (1900). An Expedition to Mount Kina Balu, British North Borneo. Journal of the Straits Branch of the Royal Asiatic Society, 34(1), 1-88.

Harrisson, T. [1938, reprint] (1988). Borneo Jungle: An Account of The Oxford University Expedition of 1932. Oxford University Press.

Holley, S. (2004). A White Headhunter in Borneo. Natural History Publications (Borneo).

Jones, L. W. [1966, reprint] (2007). The Population of Borneo: A Study of the Peoples of Sarawak, Sabah and Brunei. Opus Publications. 
eTropic 20.1 (2021) Special Issue: Pandemic, Plague, Pestilence and the Tropics

Jones, L. W. (1967). The Decline and Recovery of the Murut Tribe of Sabah. Population Studies, 21(2), 133-57. https://doi.org/10.1080/00324728.1967.10405470

Kaur, A. (1994). "Hantu" and Highway: Transport in Sabah, 1881-1963. Modern Asian Studies, 28(1), 1-49. https://doi.org/10.1017/S0026749X00011689

Korieh, C. J. (2003). Alcohol and Empire: "Illicit" Gin Prohibition and Control in Colonial Eastern Nigeria. African Economic History, 31, 111-34. https://doi.org/10.2307/3601949

Kratoska, P. H. (1990). The British Empire and the Southeast Asian Rice Crisis of 19191921. Modern Asian Studies, 24(1), 115-46. https://doi.org/10.1017/S0026749X00001189

Krishnan, P., Dali, A.M., Ghazali, A.Z., \& Subramanian, S. (2014). The History of Toddy and Its Effects on Indian Labourers in Colonial Malaya, 1900-1957. Asian Journal of Social Science, 42(3), 321-82. https://doi.org/10.1163/15685314-04203006

Lim, I. (2020, 14 July). Selangor bans smoking, vaping, alcohol drinking in playgrounds, parks for health reasons. Malay Mail. (Accessed 7 November 2020). https://www.malaymail.com/news/malaysia/2020/07/14/selangor-bans-smokingvaping-drinking-alcohol-at-playgrounds-parks-for-heal/1884387

Macaskie, C. F. C. (1922, 7 July). [Letter to Government Secretary]. (CO 874/938). TNA.

Manderson, L. (1999). Public Health Developments in Colonial Malaya: Colonialism and the Politics of Prevention. American Journal of Public Health, 89(1), 102-7. https://doi.org/10.2105/ajph.89.1.102

Massey, A. (2006). The Political Economy of Stagnation: British North Borneo Under the Chartered Company, 1881-1946. The Sabah State Archives.

Maugham, William Somerset. [1922, reprint] (2000). Far Eastern Tales. Vintage Books.

Menon, N. (2015). Battling the Bottle: Experiments in regulating drinks in late colonial Madras. The Indian Economic and Social History Review, 52(1), 29-51. https://doi.org/10.1177/0019464614561616

Merican, Z. \& Yeoh Q-L. (2004). Tapai Processing in Malaysia: A Technology in Transition. In Steinkraus, K. (ed.). Industrialisation of Indigenous Fermented Foods, (247-70). Boca Raton: CRC Press. https://doi.org/10.1201/9780203022047

Moo-Tan, S. (Ed.). (2018). The Diaries of George C. Woolley, Vol. 4. Department of Sabah Museum.

Noor, F. A. (2016). You are under arrest: Epistemic arrest and the endless reproduction of the image of the colonised native. South East Asia Research, 24(2), 185-203. https://doi.org10.1177/0967828X16649043

Pang, N., Lee, G., Tseu, M., Joss, J.I., Honey, H.A., Shoesmith, W., James, S., Loo, J.L., \& Lasimbang, H. (2020). Validation of the Alcohol Use Disorders Identification Test (AUDIT) - Dusun Version in Alcohol Users in Sabahan Borneo. Archives of Psychiatric Research, 56, 129-42. https://doi.org/10.20471/dec.2020.56.02.02

Peckham, R. (2016). Epidemics in Modern Asia. Cambridge University Press.

Peters, E. J. (2002). Attacks on a Tax: Struggles over State-Imposed Alcohol in the Villages of Northern Vietnam, 1893-1913. French Colonial History, 2, 199-216. https://doi.org/10.1353/fch.2011.0024

Pettus, K. (2019). Colonial roots of the global pandemic of untreated pain. In Koram, K. (ed.), The War on Drugs and the Global Colour Line, (196-215). Pluto Press. https://doi.org/10.2307/j.ctvdmwxn7.13

Phelan, P. R. (2001). Head-Hunting and the Magang Ceremony in Sabah. Natural History Publications (Borneo).

Polunin, I. \& Saunders, M. (1958). Infertility and Depopulation: A Study of the Murut Tribes of North Borneo. The Lancet, 272(7054), 1005-8. https://doi.org/10.1016/S01406736(58)90492-6 
eTropic 20.1 (2021) Special Issue: Pandemic, Plague, Pestilence and the Tropics

Polunin, I. (1959, 21 May). The Muruts of North Borneo and their Declining Population. [Lecture] Royal Society of Tropical Medicine and Hygiene, 312-26. https://doi.org/10.1016/0035-9203(59)90049-5

Radius, M.J. (2012, 22 April). The Rundum incident was more of a war than a rebellion. Daily Express (Malaysia). (Accessed 25 October 2020). http://www.dailyexpress.com.my/read.cfm?NewsID=882

Ramalho, R. (2020). Alcohol consumption and alcohol-related problems during the COVID19 pandemic: a narrative review. Australasian Psychiatry, 28(5), 524-6. https://doi.org/10.1177/1039856220943024

Richter, L. \& Foster, S. E. (2014). Effectively addressing addiction requires changing the language of addiction. Journal of Public Health Policy, 35(1), 60-4. https://doi.org/10.1057/jphp.2013.44

Rutter, O. [1929, reprint] (1985). The Pagans of North Borneo. Oxford University Press.

Sasges, G. (2012). State, enterprise and the alcohol monopoly in colonial Vietnam. Journal of Southeast Asian Studies, 43(1) 133-57.https://doi.org/10.1017/S0022463411000695

Saunders, D. R. (2019). Dimming the Seas around Borneo: Contesting Island Sovereignty and Lighthouse Administration amidst the End of Empire, 1946-1948. TRaNS: TransRegional and -National Studies of Southeast Asia, 7(2), 181-207. https://doi.org/10.1017/trn.2019.5

Saunders, D. R. (2020). The Friction of Distance in Borneo: Migration, Economic Change and Geographic Space in Sabah. World History Connected, 17(3). https://worldhistoryconnected.press.uillinois.edu/17.3/Sabha.html

Schler, L. (2002). Looking through a Glass of Beer: Alcohol in the Cultural Spaces of Colonial Douala, 1910-1945. The International Journal of African Historical Studies, 35(2), 315-34. https://doi.org/10.2307/3097616

Shildrick, T. (2018). Poverty Propaganda: Exploring the Myths. Bristol University Press. https://doi.org/10.2307/j.ctt22p7hzh

Simmons, J. S., Whayne, T.F., Anderson, G.W. \& Horack, H.M. (1944). Global Epidemiology: A Geography of Disease and Sanitation. William Heineman Limited.

Singh, R. D. S. (2000) The Making of Sabah, 1865-1941: The Dynamics of Indigenous Society. University of Malaya Press.

State of North Borneo Supplement to the Official Gazette. (1921). Annual Report on the West Coast Residency for 1921. (CO 648/9). TNA.

State of North Borneo Supplement to the Official Gazette. (1922). Annual Report on the West Coast Residency for 1922. (CO 648/9). TNA.

State of North Borneo, Official Gazette. (1922, 23 October). No. 15, Vol. XXXIII. (CO 874/938). TNA.

Tenom Notes. (1928, 16 May). The British North Borneo Herald. (CO 855/42). TNA, 93.

Tregonning, K. (1965). A History of Modern Sabah, 1881-1963. Singapore: University of Malaya Press.

Wald, E. (2018). Governing the Bottle: Alcohol, Race and Class in Nineteenth-Century India. Journal of Imperial and Commonwealth History, 46(3), 397-417. https://doi.org/10.1080/03086534.2018.1452546

Warren, J. A. (2013). Troublesome spirits: alcohol, excise and extraterritoriality in nineteenth and early twentieth century Siam. South East Asia Research, 21(4), 575-99. https://doi.org/10.5367/sear.2013.0176

Whitehouse, J. (1978). Of Dusun Women Entertaining. Frontiers: Journal of Women Studies, 3(3), 28-30. https://doi.org/10.2307/3346325

Williams, T. R. (1965). The Dusun: A North Borneo Society. Holt, Rinehart and Winston.

Winzeler, R. F. (2004). The Architecture of Life and Death in Borneo. University of Hawai'i Press. 
eTropic 20.1 (2021) Special Issue: Pandemic, Plague, Pestilence and the Tropics

Wong, D. T. K. (2004). Historical Sabah: Community and Society. Natural History Productions (Borneo).

Wong, D. T. K. (2009). Woolley and the Codification of Native Customs in Sabah. New Zealand Journal of Asian Studies 11(1), 87-105. https://www.nzasia.org.nz/uploads/1/3/2/1/132180707/12 wong 3.pdf

Wong, D. T. K. \& Moo-Tan, S. (Eds.). (2015). The Diaries of George C. Woolley, Vol. 1. Department of Sabah Museum.

Woolley, G.C. (1927). Two Murut Pantuns from the Dalit District, Keningau, British North Borneo. Journal of the Malayan Branch of the Royal Asiatic Society, 5(2), 366-9. https://www.jstor.org/stable/24249133

Woolley, G.C. [1936, reprint] (2004). The Timogun Muruts of Sabah. Natural History Publications (Borneo).

World Health Organisation. (2020, 27 August). Malaysia resumes polio response amidst COVID-19 pandemic. (Accessed 3 December 2020). https://www.who.int/malaysia/news/detail/27-08-2020-malaysia-resumes-polioresponse-amidst-covid-19-pandemic

Yeomans, H. (2011). What Did the British Temperance Movement Accomplish? Attitudes to Alcohol, the Law and Moral Regulation. Sociology, 45(1), 38-53.

https://doi.org/10.1177/0038038510387189

\section{Acknowledgements}

This article is based on research I conducted during my $\mathrm{PhD}$ at The University of Hong Kong, and a paper presented at the 2019 Association for Asian Studies Conference in Denver, CO. I wish to express my thanks to my fellow panel organisers and presenters: Maurits Meerwijk and Sarah Xia Yu. Our panel was instrumental in helping me refine and develop my research. Thanks are also due to the Hong Kong Research Grants Council (HKRGC) and the Hong Kong PhD Fellowship Scheme (HKPFS), which enabled me to conduct research and collect sources for this project.

Dr David R. Saunders is a historian of imperialism in Southeast Asia, with a particular interest in decolonisation, colonial governance, technology and anti-colonialism. He completed his $\mathrm{PhD}$ at The University of Hong Kong, where he recently taught a course on the end of empire in Southeast Asia. David is currently working on a manuscript that aims to present a reconceptualisation of decolonisation and state formation in Malaysia. 